\title{
STRATEGI PEMASARAN TABUNGAN PADA PT. BANK PERKREDITAN RAKYAT LA MANGAU SEJAHTERA PARIAMAN
}

\author{
Jafri, Mariani St.B Tanjung \\ Akademi Keuangan dan Perbankan Padang \\ mstbtanjung@gmail.com
}

\begin{abstract}
ABSTRAK
Penelitian ini bertujuan untuk mengetahui Bagaimana strategi yang digunakan dalam memasarkan produk serta dalam meningkatkan pemasaran produk simpanan berupa tabungan pada PT. BPR LA Mangau Sejahtera Pariaman. Untuk menganalisa data penelitian, penulis menggunakan analisa kualitatif. Dengan metode ini penulis akan mencoba memberikan fakta-fakta atau kenyataan yang dialami dengan teori-teori yang ada. PT. BPR LA Mangau Sejahtera merupakan salah satu Bank Perkreditan Rakyat yang berada di Kota Pariaman yang melakukan kegiatan penghimpunan dananya dalam bentuk tabungan dan deposito. Dalam melakukan strategi pemasarannya PT. BPR LA Mangau Sejahtera Berhasil menerapkan atau merancang strategi pemasaran dengan baik sehingga produk yang ada di BPR ini banyak diminati oleh masyarakat. Dalam penetapan bauran pemasaran, PT. BPR LA Mangau Sejahtera menciptakan produk yang berbeda dengan bank-bank lain dan tingkat bunga yang sesuai dengan ketentuan bank, tempat operasional yang strategis dan memberikan undian berhadiah setiap tahunnya pada nasabah yang menabung. Pelayanan karyawan bank dengan cara berkomunikasi yang baik dan memberikan informasi-informasi yang lengkap dan bermanfaat bagi nasabah.
\end{abstract}

Kata Kunci: Strategi Pemasaran, Bank Perkreditan Rakyat

\section{PENDAHULUAN}

Dalam persaingan dunia bisnis terutama dalam lembaga keuangan perlu adanya pengawasan guna mempermudah terjadinya transaksi. Pada dasarnya pengembangan masyarakat, ditujukan dua sasaran pokok yaitu meningkatkan kemampuan produksi, serta tercapainya lapangan kerja baru bagi angkatan kerja yang setiap tahunnya meningkat, namun dikarenakan adanya keterbasan modal produksi dalam usaha meningkatkan perekonomian tersebut, bantuan dari bank dalam bentuk tambahan modal atau yang disebut dengan kredit sangat dibutuhkan. 
Hal ini disebabkan karena kebutuhan masyarakat manusia yang beraneka ragam selalu meningkat, sementara kemampuan untuk mencapai sesuatu yang diinginkan terbatas sehingga terjadilah kesenjangan antara kemampuan dan cita-cita.

Dengan diberlakukannya Undang-Undang No. 10 Tahun 1998 sebagai perubahan dari Undang-Undang No. 7 Tahun 1992 tentang perbankan, berlakulah dua sistem dalam perbankan yang dilakukan secara konvensional dan atau berdasarkan prinsip syariah (dual banking system).

Tabungan adalah bagian dari pendapatan yang tidak dikonsumsikan. Jadi disimpan dan akan digunakan di masa yang akan datang. Pendapatan merupakan faktor utama yang terpenting untuk menentukan konsumsi dan tabungan. Keluarga-keluarga yang tidak mampu akan membelanjakan sebagian besar bahkan seluruh pendapatannya untuk keperluan hidupnya. Individu yang berpendapatan tinggi akan melakukan tabungan lebih besar dari pada individu yang berpendapatan rendah. Tabungan dapat dilakukan oleh seorang pedagang dengan membeli barang dagangan dengan maksud untuk mengkonsumsi lebih besar pada waktu yang akan datang.

Salah satu faktor yang mendorong untuk terwujudnya dan kelancaran pembangunan tersebut adalah faktor ekonomi dan lajunya faktor perekonomian yang didukung oleh berbagai faktor pula, salah satunya adalah laju tidaknya pembayaran uang di dalam masyarakat. Semakin cepat uang beredar semakin cepat laju perekonomian negara tersebut.

Dalam peredaran uang dalam masyarakat, diperlukan adanya alat perlengkapan yang potensial dan efektif untuk mengendalikan peredaran uang, dimana sebagian alat perlengkapan tersebut dapat dilakukan melalui suatu badan atau lembaga keuangan misalnya Lembaga Keuangan Bank, Lembaga Keuangan bukan Bank.

Dana-dana yang dihimpun dari masyarakat adalah dari tabungan, yang mana dana-dana tersebut masih mempunyai potensial atau masih dapat ditingkatkan. Dengan strategi pemasaran yang terencana dan terarah maka PT. BPR La Mangau Sejahtera (Bank Perkreditan Rakyat LA Mangau Sejahtera Pariaman) melakukan kebijaksanaan dalam pemasaran dengan menggunakan strategi pemasaran yang meliputi tentang produk, promosi, harga dan distribusi. Serta tingkat suku bunga yang sesuai dengan ketentuan yang berlaku dan memberikan undian berhadiah sebagai bagian dari promosi.

Dalam penulisan Tugas Akhir ini penulis membatasi strategi pemasaran hanya untuk produk tabungan. Produk tersebut merupakan produk simpanan masyarakat yang mempengaruhi aktivitas dana-dana pada PT. BPR LA Mangau Sejahtera Pariaman. Untuk meningkatkan penjualan produk simpanan maka PT. BPR LA Mangau Sejahtera Pariaman melakukan strategi pemasaran yang tepat. Berdasarkan pada uraian diatas maka penulis tertarik untuk membahas lebih jauh dalam bentuk penelitian yang berjudul "Strategi Pemasaran Tabungan Pada Pt. Bank Perkreditan Rakyat La Mangau Sejahtera Pariaman’. 


\section{Perumusan Masalah}

Sesuai dengan judul diatas, maka masalah yang dibahas dalam penelitian ini dirumuskan sebagai berikut: Bagaimana strategi yang digunakan dalam memasarkan produk serta dalam meningkatkan pemasaran produk simpanan berupa tabungan pada PT. BPR LA Mangau Sejahtera Pariaman.

\section{METODE PENELITIAN}

Metode penelitian yang dilakukan adalah :

\section{Teknik Pengumpulan Data}

a. Riset lapangan (Field Research)

Yaitu peninjauan langsung ke objek penelitian yang dipilih untuk meneliti hasil data primer. Penelitian langsung ke lapangan ini akan dapat membantu penulis untuk melengkapi data yang diperlukan. Adapun cara riset lapangan ini adalah dengan mewawancarai langsung pihak-pihak yang berkepentingan, dalam hal ini adalah perusahaan atau instansi yang terkait.

\section{b. Riset perpustakaan (Library Research)}

Yaitu penelitian yang dilakukan melalui perpustakaan ataupun buku ilmiah atau tulisan-tulisan yang ada hubungannya dengan pembahasan yang dilakukan.

\section{Teknik Analisa Data}

Untuk menganalisa data penelitian, penulis menggunakan analisa kualitatif. Dengan metode ini penulis akan mencoba memberikan fakta-fakta atau kenyataan yang dialami dengan teori-teori yang ada.

\section{LANDASAN TEORI}

\section{Definisi dan Fungsi Bank}

Bank menurut Undang-Undang No. 10 tahun 1998 adalah badan usaha yang menghimpun dana dari masyarakat dalam bentuk simpanan dan menyalurkannya kepada masyarakat dalam bentuk kredit dan atau bentukbentuk lainnya dalam rangka meningkatkan taraf hidup rakyat banyak.

Secara lebih luas bahwa bank merupakan perusahaan yang bergerak dibidang keuangan artinya: Perbankan selalu berkaitan dengan keuangan. Berdasarkan definisi mengenai bank dapat dinyatakan fungsi bank sebagai berikut:

1. Sebagai lembaga yang menghimpun dana dari masyarakat.

2. Sebagai lembaga yang menyalurkan dana kepada masyarakat dalam bentuk kredit dan sebagai lembaga pemberiaan kredit.

3. Sebagai lembaga yang melancarkan transaksi perdagangan dan pembayaran hutang. 


\section{Definisi Pemasaran}

Pemasaran adalah satu fungsi organisasi dan seperangkat proses untuk menciptakan, mengomunikasikan, dan menyerahkan nilai kepada pelanggan dan mengelola hubungan pelanggan dengan cara yang menguntungkan organisasi dan para pemilik sahamnya. (Philip Kotler dan Kevin Lane Koller 2007: 6).

Pemasaran adalah kegiatan manusia yang diarahkan untuk memuaskan kebutuhan dan keinginan melalui proses pertukaran. (Murti Sumarni 1993)

Dari beberapa definisi diatas dapat disimpulkan bahwa pemasaran merupakan suatu kegiatan bisnis untuk memuaskan kebutuhan pelanggan baik produsen maupun konsumen. Kepuasan berarti membeli barang dengan harga yang tepat dan bermanfaat melalui penggunaan barang dan jasa tersebut. Sedangkan kepuasan produsen berarti keuntungan yang diperoleh dengan mengusahakan adanya pengeluaran tertentu untuk memproduksi barang dan jasa serta menyalurkannya kepada konsumen dengan cara yang tepat dan bermanfaat bagi pengguna, yang mengakibatkan terjadinya penawaran.

\section{Strategi Pemasaran}

Strategi pemasaran merupakan hal yang sangat penting bagi perusahaan dimana strategi pemasaran merupakan suatu cara mencapai tujuan dari sebuah perusahaan. Menurut (Philip Kotler dan Gary Amrstrong 2001 : 5) mengemukakan pemasaran adalah suatu proses sosial dan manajerial yang membuat individu dan kelompok memperoleh apa yang mereka butuhkan dan inginkan lewat penciptaan dan pertukaran timbal balik produk dan nilai dengan orang lain.

Strategi adalah rencana yang disatukan, luas dan terintegrasi yang menghubungkan keunggulan strategis perusahaan dengan tantangan lingkungan dan yang dirancang untuk memastikan bahwa utama dari perusahaan itu dapat dicapai melalui pelaksanaan yang tepat oleh organisasi. ( William F. Glueck dan Lawrence R. Jauch 1990 : 9 )

Untuk dapat menunjang peningkatan jumlah nasabah atau konsumen maka setiap perusahaan harus membagi seluruh pasar, memilih segmen terbaik, dan merancang strategi untuk melayani pilihan segmen yang lebih menghasilkan laba dari pada pesaingnya, proses ini terdiri dari tiga langkah, menurut ( Rambat Lupiyoadi ) yaitu :

1. Segmentasi Pasar (Market Segmentation)

Membagi pasar menjadi kelompok pembeli yang dibedakan menurut kebutuhan, karakteristik, atau tingkah laku, yang mungkin membutuhkan produk yang berbeda.

2. Menetapkan Pasar sasaran (Market Targeting)

Pasar sasaran terdiri dari kumpulan pembeli dengan kebutuhan atau karakteristik serupa yang akan dilayani perusahaan.

3. Menempatkan Posisi Pasar (Market Positioning) 
Merupakan konsep psikologis yang terkait dengan bagaimana konsumen yang ada ataupun calon konsumen dapat menerima perusahaan tersebut dan produknya dibandingkan dengan perusahaan lain.

\section{Bauran Pemasaran ( Marketing Mix )}

Bauran pemasaran adalah seperangkat alat pemasaran taktis yang dipadukan untuk menghasilkan respon yang diinginkan pasar sasaran.

Bauran pemasaran terdiri dari atas segala sesuatu yang dapat dilakukan perusahaan untuk mempengaruhi permintaan produknya, agar dapat melakukan penghimpunan masyarakat, bank memerlukan adanya suatu strategi pemasaran yang baik.

Elemen-elemen yang biasa digunakan dalam perusahaan jasa (bank) menurut (Rambat Lupiyoadi dan A. Amstrong) yaitu :

1. Produk (Product)

Konsumen tidak hanya membeli fisik dari produk tetapi manfaat dan nilai dari produk yang disebut "the offer". Keunggulan produk jasa terletak pada kualitasnya, yang mencakup keandalan, ketanggapan, kepastian dan empati. mengembangkan nilai tambah produk selain keistimewaan dasarnya, agar dapat dibedakan dengan produk lain dan memiliki citra sendiri. Dengan demikian, produk akan mampu bersaing.

Pengertian produk menurut (Philip Kotler 2000 : 448) adalah segala sesuatu yang dapat ditawarkan ke suatu pasar untuk memenuhi keinginan dan kebutuhan.

2. Harga (Price)

Keputusan dalam penentuan harga harus konsisten dengan strategi pemasaran. Strategi penentuan harga harus memperhatikan tujuan penentuan harga, memaksimalkan harga, memaksimalkan penjualan, gengsi atau prestis, pengembalian atau investasi. Faktor-faktor seperti positioning jasa, siklus hidup jasa merupakan hal yang mempengaruhi penentuan harga dalam bisnis jasa.

Pengertian Price menurut (Rambat Lupiyoadi 2001 : 61) adalah keputusan dalam harga harus konsisten dengan strategi pemasaran secara keseluruhan.

3. Tempat (Place)

Tempat dapat bisnis jasa dimaksudkan sebagai cara penyampaian jasa (delivery system) kepada konsumen dan dimana lokasi yang strategis.

Pengertian Place menurut (Rambat Lupiyoadi, 2001:61) adalah merupakan gabungan antara lokasi dan keputusan atas saluran distribusi, dalam hal ini berhubungan dengan bagaimana cara penyampaian jasa kepada konsumen dan dimana lokasi yang stategis.

Ada tiga pihak sebagai kunci keberhasilan yang perlu dilibatkan dalam penyampaian jasa, yaitu : 
a) Penyedia Jasa

b) Perantara

c) Konsumen

Pilih tempat yang strategis dengan sistem penjualan langsung, jika pasar menginginkan pengiriman yang cepat, tepat waktu, dan sifat barang yang tidak tahan lama.

4. Promosi (Promotion)

Keberhasilan promosi jasa tergantung pada :

a) Kemampuan mengidentifikasi audiens target sesuai segmen pasar

b) Kemampuan menentukan tujuan promosi: apakah untuk menginformasikan, memengaruhi, atau mengingatkan.

c) Kemampuan mengembangkan pesan yang disampaikan: terkait dengan isi pesan (apa yang harus disampaikan), struktur pesan (bagaimana menyampaikan pesan secara logis), gaya pesan (ciptakan bahasa yang kuat), dan sumber pesan (siapa yang harus menyampaikannya).

d) Kemampuan memilih bauran komunikasi : apakah komunikasi personal atau komunikasi nonpersonal.

Menurut (Rambat Lupiyoadi 2001 : 108) untuk dapat membantu penjualan produk atau jasa secara umum dapat digunakan melalui media komunikasi yang tercangkup dalam bauran promosi :

a) Advertising (Periklanan)

Promosi melalui periklanan merupakan salah satu bentuk dari komunikasi impersonal (Impersonal communication) yang digunakan oleh perusahaan baik barang/jasa.

b) Personal Selling (Penjualan Secara Pribadi)

Personal Selling mempunyai peranan yang penting dalam pemasaran jasa, karena :

1) Interaksi secara personal antara penyedia jasa dan konsumen sangat penting.

2) Jasa tersebut disediakan oleh orang bukan oleh mesin.

3) Orang merupakan bagian dari produk jasa.

c) Sales Promosion (Promosi Penjualan)

Sales Promosion adalah kegiatan yang dimaksudkan untuk meningkatkan arus barang atau jasa dari produsen sampai pada penjualan akhirnya.

d) Public Relation (Hubungan Masyarakat)

Public Relation merupakan kiat pemasaran penting lainnya, dimana perusahaan tidak harus berhubungan hanya dengan pelanggan, pemasok, dan penyalur, tetapi ia juga harus berhubungan dengan kumpulan kepentingan publik yang lebih besar. 
5. Orang (People)

Orang berfungsi sebagai penyedia jasa sangat mempengaruhi kualitas jasa yang diberikan. Untuk mencapai kualitas di perlukan pelatihan staf sehingga karyawan mampu memberikan kepuasan kepada konsumen. Orang yang dalam pemasaran jasa berkaitan erat dengan pemasaran internal, merupakan interaksi setiap karyawan dan departement dalam suatu perusahaan sebagai konsumen internal dan pemasok internal. Tujuannya untuk mendorong orang dalam kinerja memberikan kepuasan kepada konsumen.

6. Proses (Process)

Proses dalam pemasaran terkait dengan kualitas yang diberikan, terutama dalam hal sistem penyampaian. Terdapat pilihan-pilihan dalam unsur proses untuk menghasilkan kualitas jasa, yaitu :

a) Kemampuan membangun proses yang menghasilkan pengurangan biaya, peningkatan produktivitas, dan kemudahan distribusi. Hal ini terkait dengan unsur mengurangi keragaman.

b) Kecenderungan memperbanyak kustomisasi dan fleksibilitas dalam produksi yang mampu menimbulkan naiknya harga. Aktivitas ini terkait dengan unsur menambah keragaman.

c) Kecenderungan menciptakan spesialisasi yang terkait dengan unsur mengurangi kompleksitas.

d) Kemampuan melakukan penetrasi pasar dengan cara menambah pelayanan yang diberikan. Hal ini terkait dengan menambah kompleksitas.

7. Layanan Pelanggan (Customer Service)

Layanan pelanggan mengarah pada aktivitas pelayanan pratransaksi, saat transaksi dan pascatransaksi. Kegiatan sebelum transaksi akan turut memengaruhi kegiatan transaksi dan setekah transaksi. Tujuan dari aktivitas ini adalah agar nasabah memberi respon yang positif dan menunjukkan loyalitas yang tinggi.

Melakukan strategi layanan nasabah dengan mengenali tugas, menentukan sasaran dari layanan nasabah, merumuskan strategi, dan menerapkan strategi layanan nasabah yang dipilih.

\section{ANALISA DAN PEMBAHASAN}

Bauran Pemasaran yang dilakukan oleh PT. BPR LA Mangau Sejahtera Pariaman

Pengertian tabungan berdasarkan perubahan atas Undang-Undang Nomor 7 tahun 1992 tentang perbankan ( Undang-Undang Republik Indonesia No. 10 tahun 1998 ) adalah simpanan yang penarikannya hanya dapat dilakukan menurut syarat-syarat tertentu yang disepakati, tetapi tidak 
dapat ditarik dengan cek, bilyet giro, dan atau alat lainnya yang dipersamakan dengan itu.

Agar penghimpunan dan penyaluran dana itu meningkat dari tahun ke tahun PT. BPR LA Mangau Sejahtera Pariaman menerapkan kegiatan pemasaran yang terencana dan terarah. Untuk melihat tingkat keberhasilan pemasaran yang telah dilakukan suatu bank dapat dilihat dari segi marketing mix.

PT. BPR LA Mangau Sejahtera Pariaman menggunakan kebijaksanaan pemasaran yang terdiri dari kebijaksanaan produk, harga, promosi, distribusi, orang, proses dan layanan pelanggan.

A. Produk ( Product)

Produk merupakan hal utama yang harus ada dalam pemasaran, adapun produk penghimpunan dana yang disediakan oleh PT. BPR LA Mangau Sejahtera Pariaman adalah :

1) Tabungan

Yaitu simpanan yang penarikannya hanya dapat dilakukan menurut syaratsyarat tertentu yang disepakati, tetapi tidak dapat ditarik dengan cek, bilyet giro, dan atau alat lainnya yang dipersamakan dengan itu.

Ada dua cara yang dilakukan oleh PT. BPR LA Mangau Sejahtera Pariaman untuk memperoleh dana tabungan dari masyarakat :

a) Sistem tabungan dijemput yaitu tabungan yang diperoleh dengan cara dijemput oleh pihak bank kerumah masing-masing nasabah.

b) Sistem tabungan biasa yaitu tabungan yang dilakukan masyarakat atau nasabah dengan cara langsung datang untuk menabung ke bank tersebut.

Jenis-jenis tabungan pada PT. BPR LA Mangau Sejahtera Pariaman adalah :

a) Tabungan Anak Nagari ( TAN )

Yaitu tabungan yang diselenggarakan oleh PT. BPR LA Mangau Sejahtera Kuraitaji Pariaman, produk simpanan dalam bentuk tabungan yang ditujukan untuk masyarakat Kota Pariaman. Tabungan ini satu-satunya tabungan di PT. BPR LA Mangau Sejahtera Pariaman yang di undi setiap tahunnya. Tingkat bunga dari tabungan anak nagari ini adalah $6 \%$.

b) Tabungan Pelajar / Simpanan pelajar

Yaitu produk simpanan dalam bentuk tabungan yang ditujukan untuk pelajar/siswa, dalam rangka menumbuh kembangkan semangat dan kebiasaan menabung pelajar di Kota Pariaman. Tingkat bunga dari tabungan pelajar ini adalah $4 \%$.

c) Tabungan Masa Depan 
Yaitu produk simpanan dalam bentuk tabungan yang ditujukan untuk masyarakat umum dalam rangka untuk mencapai cita-cita dimasa yang akan datang. Tingkat bunganya adalah $4 \%$.

2) Deposito

Deposito adalah simpanan yang penarikannya hanya dapat dilakukan pada waktu tertentu berdasarkan perjanjian nasabah penyimpan dengan bank.

Fasilitas yang dapat diperoleh adalah :

a) Deposito dalam rupiah.

b) Bunga deposito bersaing.

c) Jangka waktu dapat dipilih antara 1 bulan, 3 bulan, 6 bulan, dan 12 bulan dan dapat diperpanjang secara otomatis.

d) Bunga dapat diambil setiap bulan atau dipindahbukuan ke rekening tabungan.

Ketentuan pengambilan deposito yang diambil sewaktu-waktu adalah :

a) Jangka diambil sebelum jangka waktu penyimpanan 1 bulan tidak akan mendapat bunga.

b) Jangka diambil sesudah waktu penyimpanan 1 bulan akan tetapi kurang dari 3 bulan diberikan bunga perbulan sejak tanggal pendepositoan.

c) Jika diambil sesudah waktu penyimpanan 3 bulan akan tetapi kurang dari 6 bulan diberikan bunga berjalan perbulan sejak tanggal pendepositoan.

d) Jika diambil sesudah waktu penyimpanan 6 bulan tapi kurang dari 12 bulan diberi bunga berjalan perbulan sejak tanggal pendepositoan.

e) Jika diambil sesudah jangka waktu 12 bulan akan tetapi kurang dari 24 bulan diberi bunga berjalan perbulan sejak tanggal pendepositoan.

B. Harga (Price)

Yang harus diperhatikan oleh PT. BPR LA Mangau sejahtera Pariaman dalam penetapan harga adalah bahwa harga produk bank tidak dapat diukur dari bunga semata, tetapi juga dari kepuasan nasabah dan bank ini sendiri. Dengan demikian penetapan harga oleh pihak bank harus dihubungkan dengan :

1) Bagaimanakah nasabah menerima harga produk yang ditawarkan oleh bank.

2) Nilai subjektif dari kedua belah pihak ( Bank dan Nasabah )

Kebijakan penetapan tingkat bunga oleh PT. BPR LA Mangau Sejahtera Pariaman dilakukan dengan menetapkan tingkat bunga tabungan lebih rendah dari pada tingkat bunga deposito. Hal ini dikarenakan oleh simpanan deposito lebih pasti, sementara simpanan berupa tabungan penarikannya dapat dilakukan sewaktu-waktu. 


\section{Tempat (Place)}

Untuk dapat mencapai sasaran produk atau jasa bank, maka diupayakan agar selalu dekat dengan nasabah untuk menjalin hubungan antara nasabah dengan bank dan bank juga menawarkan adanya suatu jaringan kerja yang cukup.

Dalam menjalankan kegiatan usahanya yaitu dalam penghimpunan dana masyarakat PT. BPR LA Mangau Sejahtera Pariaman melakukan kegiatan operasionalnya di Pasar Kuraitaji Pariaman Barat. Lokasi ini strategis karena dekat dengan rumah penduduk, sekolah, pedagang dan instansi pemerintah, karena lokasi ini dekat dengan masyarakat, maka PT. BPR LA Mangau Sejahtera juga menugaskan kepada karyawan untuk melakukan penjemputan langsung pada nasabah yang ingin menyimpan uangnya. Hal ini dilakukan dalam rangka meningkatkan pelayanan kepada masyarakat.

D. Promosi (Promotion)

Aktivitas promosi yang dilakukan oleh PT. BPR LA Mangau Sejahtera Pariaman dalam menghimpun dana masyarakat adalah sebagai berikut :

1) Periklanan

Kebijaksanaan periklanan dilakukan melalui brosur-brosur yang keluar disebarkan kepada masyarakat, sementara papan reklame yang dipasang di depan kantor PT. BPR LA Mangau Sejahtera Pariaman sendiri.

2) Promosi Penjualan

Kebijaksanaan promosi penjualan dilakukan dengan cara melakukan penarikan undian berhadiah terhadap dana masyarakat, khususnya untuk produk tabungan. Masing-masing jenis tabungan memiliki kelebihan yaitu pada Tabungan Anak Nagari dilakukan penarikan undian satu kali dalam setahun yang hadiahnya berupa barang elektronik dan kendaraan.

3) Personal selling

Kebijakan personal selling dilakukan dengan cara menugaskan karyawan untuk langsung mempromosikan produk penghimpunan dana kepada masyarakat, baik yang sudah menjadi nasabah maupun masyarakat calon nasabah pada PT. BPR LA Mangau Sejahtera Pariaman seperti : pedagang, sekolah-sekolah, pegawai negrei dan lain-lain.

4) Promosi melalui pembayaran listrik

Promosi melalui pembayaran listrik dilakukan oleh karyawan pada waktu nasabah melakukan pembayaran listiknya di BPR LA Mangau Sejahtera dan menawarkan produk yang ada di bank itu sendiri.

E. Orang (People)

Sehubungan dengan meningkatnya aktivitas usaha, untuk memberikan pelayanan yang memuaskan maka PT. BPR LA Mangau Sejahtera Pariaman 
selalu memperbaiki kualitas sumber daya manusianya dan terus memantau apa yang dikerjakan karyawan. Peningkatan sumber daya manusia yang dilakukan antaranya dengan :

1) Melakukan perbaikan kesejahteraan pegawai melalui program kerja.

2) Meningkatkan pengetahuan, kemampuan dan keterampilan pegawai.

3) Menerapkan aturan-aturan yang bermanfaat supaya karyawan bank disiplin dalam bekerja.

F. Proses (Process)

Prosedur yang diterapkan oleh PT. BPR LA Mangau Sejahtera Pariaman dalam menghimpun dana masyarakat adalah :

1) Prosedur Pembukaan Rekening Tabungan

a) Menerima permohonan pembukaan rekening tabungan dari calon penabung dan memberikan penjelasan kepada calon penabung untuk mengenai persyaratan dan suku bunga yang berlaku.

b) Meminta penabung untuk mengisi formulir pembukuan rekening tabungan yang mencantumkan identitas penabung yaitu nama penabung, tempat / tanggal lahir, pekerjaan, alamat, ahli waris yang ditunjuk, nomor KTP/SIM/ Kartu Pelajar dilampiri foto copy serta formulir Kwep untuk antisipasi money loundring.

c) Meminta calon penabung untuk mengisi slip setoran tabungan yang telah disediakan oleh bank.

d) Menyamakan data yang dicantumkan pada formulir pembukuan dan data kartru identitas calon penabung termasuk tanda tangannya, kalau belum lengkap maka kepada calon penabung disuruh untuk melengkapinya.

e) Input buku rekening tabungan ke dalam sistem pembukuan BPR, nomor rekening dan nomor buku tabungan secara otomatis akan terekam oleh sistem dan akan terdaftar dalam daftar tabungan serta melakukan pencetakan pada buku tabungan.

f) Meminta penabung untuk membuat tanda tangannya pada buku tabungan sesuai dengan tempat yang tersedia. Dan mencocokkan tanda tangan pada buku tabungan yang telah ditanda tangani oleh penabung pada formulir pembukuan tabungan dan pada kartu calon identitas calon penabung.

g) Setelah melakukan pemeriksaan oleh petugas tabungan dan Kepala Bagian Dana, maka sampai pada bagian Teller yang menerima setoran awal nasabah, melakukan proses input tabungan serta cetak buku dan kemudian diserahkan kepada nasabah.

2) Prosedur Pembukaan Deposito

a) Menerima permohonan pembukaan rekening deposito dari calon deposan. 
b) Memberikan penjelasan kepada calon deposan untuk mengenal jenis ketentuan, persyaratan serta bunga deposito yang berlaku.

c) Meminta deposan untuk mengisi formulir pembukuan rekening deposito yang mencantumkan identitas deposan sesuai dengan syaratsyarat dan ketentuan yang berlaku.

d) Meminta deposan untuk mengisi slip setoran deposito yang telah disediakan.

e) Menyamakan data yang tercantum pada formulir pembukaan pada data kartu identitas calon deposan termasuk tanda tangannya, bila belum sesuai atau lengkap maka diminta kepada calon deposan untuk melengkapinya.

f) Input pembukuan rekening deposito ke dalam sistem pembukuan BPR nomor rekening dan nomor buku deposito secara otomatis akan terekam oleh sistem dan akan terdaftar dalam daftar deposito.

g) Catatan nomor rekening deposito pada formulir pembukuan deposito dan slip setoran serta melakukan pencetakan data deposan pada buku deposito.

h) Meminta calon deposan untuk membuat tanda tangannya pada buku deposito yang tersedia dan mencocokkan tanda tangan pada formulir pembukuan deposito dan pada kartu identitas calon deposan.

i) Setelah melakukan pemeriksaan oleh petugas deposan dan Kepala Bagian dana, maka sampai pada bagian Teller yang menerima setoran awal nasabah, melakukan proses input deposito serta cetak kartu buku yang kemudian diserahkan kepada nasabah.

G. Pelayanan Nasabah (Customer Service)

Dalam melayani nasabah hal-hal yang perlu diperhatikan adalah kepuasan nasabah terhadap pelayanan yang diberikan. Kepuasan nasabah artinya nasabah akan merasa semua keinginannya dan kebutuhannya dapat dilakuakan secara tepat waktu.

Untuk meningkatkan pelayanan pada masyarakat atau nasabah, maka PT. BPR LA Mangau Sejahtera Pariaman melakukan hal-hal sebagai berikut :

1) Menyediakan tempat atau kantor dan ruang tunggu yang memadai, dengan tata ruang yang nyaman sehingga nasabah merasa nyaman bila memasuki kantor BPR.

2) Tata ruang kerja karyawan yang sangat mendukung sehingga dapat meningkatkan semangat karyawan bekerja.

3) Petugas customer service harus ramah, sopan dan menarik. Serta cepat tanggap, pandai bicara menyenangkan dan pintar. Petugas customer service harus memikat nasabah sehingga nasabah tertarik.

4) Bertanggung jawab kepada setiap nasabah sejak awal hingga selesai, dalam menjalankan kegiatan pelayanan customer service harus mampu melayani dari awal sampai tuntas atau selesai. 
5) Mampu memberikan kepercayaan kepada nasabah, kepercayaan calon nasabah kepada bank mutlak diperlukan sehingga calon nasabah mau menjadi nasabah bank yang bersangkutan. Demikian pula untuk menjaga nasabah yang lama agar tidak lari perlu dijaga kepercayaannya.

6) Berkomunikasi yang baik kepada nasabah.

7) Memberikan informasi yang lengkap, bermanfaat dan mudah dimengerti oleh nasabah.

Kendala Yang Dihadapi PT. BPR LA Mangau Sejahtera Pariaman dalam strategi pemasaran tabungan

Kendala yang dihadapi oleh PT. BPR LA Mangau Sejahtera Pariaman dalam meningkatkan strategi pemasaran tabungan adalah :

1. Persaingan

Persaingan merupakan salah satu kendala yang dihadapi oleh bank, persaingan merupakan suatu kondisi yang melekat pada suatu perusahaan yang memasuki suatu pasar, dimana pasar tersebut mendapat sejumlah prosedur dan konsumen serta berbagi macam barang atau jasa yang diperjualbelikan. Demikian pula hal nya dengan perusahaan perbankan dimana antaranya jasa-jasa atau hakekat-hakekat bukanlah suatu permasalahan baru tapi merupakan suatu kondisi.

2. Kendaraan

Kendalanya disini adalah bahwa PT. BPR LA Mangau Sejahtera Pariaman mengalami kekurang kendaraan untuk melakukan aktivitas di lapangan.

\section{KESIMPULAN}

Dari uraian di atas dapat diambil kesimpulan dari strategi pemasaran tabungan yang dilakukan oleh PT. BPR LA Mangau Sejahtera Pariaman yaitu sebagai Berikut :

1. PT. BPR LA Mangau Sejahtera merupakan salah satu Bank Perkreditan Rakyat yang berada di Kota Pariaman yang melakukan kegiatan penghimpunan dananya dalam bentuk tabungan dan deposito.

2. Dalam melakukan strategi pemasarannya Pt. BPR LA Mangau Sejahtera Berhasil menerapkan atau merancang strategi pemasaran dengan baik sehingga produk yang ada di BPR ini banyak diminati oleh masyarakat.

3. Dalam penetapan bauran pemasaran, PT. BPR LA Mangau Sejahtera menciptakan produk yang berbeda dengan bank-bank lain dan tingkat bunga yang sesuai dengan ketentuan bank, tempat operasional yang strategis dan memberikan undian berhadiah setiap tahunnya pada nasabah yang menabung.

4. Pelayanan karyawan bank dengan cara berkomunikasi yang baik dan memberikan informasi-informasi yang lengkap dan bermanfaat bagi nasabah. 


\section{DAFTAR PUSTAKA}

Afrianto, D., \& Afriyeni, A. (2019). Aktivitas Penghimpunan Dana Tabungan Pada PT. Bank Pembangunan Daerah (BPD) Sumatera Barat Cabang Utama Padang. https://doi.org/10.31219/osf.io/ackfh

Andika, A., \& Susanti, F. (2018). Pengaruh Marketing Mix Terhadap Keputusan Pembelian Parfum di Azzwars Parfum Lubeg Padang. https://doi.org/10.31227/osf.io/upgc3

Aziz, N. (2019). Pengaruh Strategi Promosi Terhadap Keputusan Pembelian Yang Dimediasi Oleh Minat Beli Pada Konsumen Restoran KFC Cabang Khatib Sulaiman Padang. https://doi.org/10.17605/OSF.IO/V92TS

Aziz, N. (2019). Analisis Pengaruh Kualitas Produk, Harga, Promosi Terhadap Keputusan Pembelian Air Minum Dalam Kemasan (AMDK) Merek Aicos Produksi PT. Bumi Sarimas https://doi.org/10.17605/OSF.IO/8XKYB

F. Glueck William dan Lawrence R. Jauch "Manajemen Strategis dan Kebijakan Perusahaan", Edisi ke 2, Penerbit Erlangga, Jakarta 1990 : 9.

Fernandes, Y. D., \& Marlius, D. (2018). Peranan Customer Service Dalam Meningkatkan Pelayanan Kepada Nasabah Pada PT. Bank Pembangunan Daerah Sumatera Barat Cabang Utama Padang. https://doi.org/10.31227/osf.io/wrh3p

F., \& Afriyeni, A. (2019). Aktivitas Pemasaran Produk Tabungan Pada PT. Bank Pembangunan Daerah (BPD) Sumatera Barat Cabang Utama Padang. https://doi.org/10.31219/osf.io/tf2bz

Hidayati, R. R., \& Marlius, D. (2018). Aktivitas Promosi Dalam Meningkatkan Dana Pihak Ketiga Pada PT. Bank Perkreditan Rakyat (BPR) Batang Kapas Pesisir Selatan. https://doi.org/10.31227/osf.io/8dgqn

Jamarnis, S., \& Susanti, F. (2019). Pengaruh Harga Dan Periklanan Melalui Internet Terhadap Keputusan Pembelian Produk Sabun Merek Lux Pada Mahasiswa STIE “KBP” Padang. https://doi.org/10.31227/osf.io/xz3d8

Lupiyoadi Rambat dan A. Hamdani "Manajemen Pemasaran Jasa", Edisi ke 2, Penerbit Salemba Empat, Jakarta 2008 : 81. 
Lupiyoadi Rambat "Manajemen Pemasaran Jasa Teori dan praktik", Edisi Pertama, Penerbit Salemba Empat, Jakarta 2001.

Kotler Philip dan Gary Amstrong "Prinsip-Prinsip Pemasaran”, Edisi ke 8, Penerbit Erlangga, Jakarta 2001.

Kotler Philip "Manajemen Pemasaran", Edisi Millenium, Penerbit Prenhallindo, jakarta 2000.

Kotler Philip "Manajemen Pemasaran", Edisi 12, Penerbit PT. Macanan Jaya Cemerlang, 2007.

Marlius, D. (2017). Keputusan Pembelian Berdasarkan Faktor Psikologis Dan Bauran Pemasaran Pada PT. Intercom Mobilindo Padang. Jurnal Pundi. Volume 1. No. 1. Hal. 57-66. https://doi.org/10.31575/jp.v1i1.9

Marlius, D. (2016). Pengaruh Bauran Pemasaran Jasa Terhadap Minat Nasabah Dalam Menabung Pada Bank Nagari Cabang Muaralabuh. https://doi.org/10.31227/osf.io/vdqgx

Mayliza, R. (2019). Pengaruh Kesadaran Merek, Asosiasi Merek Dan Perception Of Quality Terhadap Keputusan Pembelian Hospital Bed Merek Paramout Di PT. Aga Medika Utama Padang (Studi Kasus Rumah Sakit Umum Kota Padang). https://doi.org/10.17605/OSF.IO/VYQ4E

Mulyadi, H., \& Susanti, F. (2018). Pengaruh Penerapan Strategi Customer Relationship Marketing Terhadap Kepuasan Nasabah Pada PT. Pro Car International Finance Cabang Padang. https://doi.org/10.31227/osf.io/bhq8d

E Cushing Barry dan Ruchyat kosasih "Sistem Informasi Akuntansi dan Organisasi Perusahaan”, Edisi Ketiga, Penerbit Erlangga, Jakarta, 1982.

P. Siagian Sondang "Peranan Staf Dalam Managemen", Penerbit PT. Enka Parahiyangan, Jakarta, 1981.

Priyanti,Y. Susanti, F. Aziz, N. (2017). Minat Beli Konsumen Toko Sepatu Bata Dipasar Raya Padang Dilihat Dari Sikap Dan Iklan. Jurnal Pundi, Vol. 01, No. 02

Safitri, R. N., \& Marlius, D. (2017). Penerapan E-Banking Dalam Meningkatkan Jasa Dan Layanan Perbankan Di PT. Bank Rakyat Indonesia Cabang Padang. https://doi.org/10.31227/osf.io/gkv8t 
Sumarni Murti “Marketing Perbankan", Edisi ke 3, Penerbit Liberty, Yogyakarta, 1996.

Susanti, F. (2015). Pengaruh Bauran Promosi Terhadap Keputusan Klien Dalam Memilih Radio Carano Sebagai Media Promosi Iklan. https://doi.org/10.31227/osf.io/b9ws7

Susanti, F. (2014). Pengaruh Tarif Iklan Terhadap Pendapatan Pada PT. Radio Swara Carano Batirai Indah Batusangkar. https://doi.org/10.31227/osf.io/dy863

Susanti, F. (2018). Faktor Faktor Yang Mempengaruhi Minat Beli Pada E-Commerce Lazada.co.id (Studi Pada Mahasiswa Jurusan S1 Manajemen "STIE KBP" Padang). https://doi.org/10.31227/osf.io/um4yw

Susanti, F., \& Gunawan, A. C. (2019). Pengaruh Bauran Promosi Dan Harga Terhadap Keputusan Pembelian Produk Kosmetik Maybelline Di Kota Padang. https://doi.org/10.31227/osf.io/npjqh

Wahyuni, S. V., \& Afriyeni, A. (2019). Aktivitas Penghimpunan Dana Deposito Pada PT. Bank Pembangunan Daerah (BPD) Sumatera Barat Cabang Lintau. https://doi.org/10.31219/osf.io/g67d2

Widayati, R. (2019). Promotional Activities And Services Bank Nagari Kambang Increase In Customer. https://doi.org/10.17605/OSF.IO/MYAVT

Widayati, R. (2019). Aktivitas Pemasaran Produk Tabungan Pada PT. Bpr Rangkiang Denai Payakumbuh Barat. https://doi.org/10.17605/OSF.IO/S3UZM

Widayati, R. (2019). Aktivitas Pemasaran Produk Simpanan PT. Bank Tabungan Negara (Persero) Tbk Kantor Cabang Padang. https://doi.org/10.17605/OSF.IO/3Z5YC 